\title{
PENGUATAN PENDIDIKAN KARAKTER ANAK USIA DINI PADA BUKU KUMPULAN DONGENG PAUD KEISTIMEWAAN BINATANG
}

Kasmiati

Institut Agama Islam Negeri (IAIN) Palu

kasmiati@gmail.com

Abstrak: Hasil pelitiannya adalah pertama, buku Kumpulan Dongeng PAUD: Keisitimewaan Binatang menghadrikan lima penguatan pendidikan karakter, yaitu karakter religius, karakter nasionalis, karakter mandiri, karakter gotong-royong, dan karakter integritas. Setiap karakter ini disajikan dalam dongeng-dongeng yang ada dibuku dengan direpresentasikan oleh tokoh-tokoh binatang yang menjadi tokoh utama penceritaan dalam dongeng. Kelima penguatan pendidikan karekter ini disajikan dalam cerita dongeng-dongeng yang menarik dari aspek narasi, isi-materi, dan ilustrasi yang dampaknya membuat anak-anak suka dengan dongeng-dongeng buku ini. Rasa suka inilah yang membuat proses penguatam pendidikan karakter terjadi. Kedua, penguatan pendidikan karakternya terbentuk melalui rasa suka anak-anak usia dini dengan dongeng-dongeng dalam buku ini, sehingga anak-anak usia dini antusias saat dibacakan buku dongeng ini. Sikap antusias ini membuat anak-anak usia dini suka dengan cerita dalam dongeng. Rasa suka ini kemudian membuat anak-anak usia dini paham dengan isi dongeng, yang kemudian mengkondisikan anak-anak usia dini untuk melakukan refleksi, yaitu menghubungan isi cerita dan nilai karakter dalam dongeng dengan kehidupan sehari-hari anak. Dari sinilah anak-anak kemudian melakukan penguatan pendidikan karakter religius, nasionalis, mandiri, gotong-royong, dan integritas dalam diri anak-anak. Dari sinilah, proses penguatan pendidikan karakter terbentuk dan terjadi dengan media buku Kumpulan Dongeng PAUD: Keistimewaan Binatang.

Kata Kunci: dongeng, karakter, religius, nasionalis, mandiri, gotong-royong, dan integritas, anak usia dini.

Abstract: The results of this research are first, the early childhood book Tales Collection: Privilege of Animal presents five reinforcement of character education, namely religious, nationalist, independent, mutual cooperation, and integrity characters. Each of these characters is presented in fairy tales in the book, represented by animal figures which are be the main characters in storytelling. The five strengthening of this character education is presented in interesting fairy tales from the aspects of narration, content, and illustrations which the impact makes children love with the fairy tales of this book. This feeling of love that makes the process of strengthening character education happen. Second, the strengthening of character education is formed through the love of early childhood with the tales in this book, so that young children are enthusiastic when reading this fairytale book. This enthusiasm makes early childhood love stories in the 


\section{Kasmiati}

fairy tales. This fondness then makes young children understand the contents of fairy tales, which then conditions young children to reflect, that is connecting the contents of the story and the value of characters in fairy tales with the daily life of children. From this the children then strengthened the character education of religious, nationalist, independent, mutual cooperation, and integrity in children. From here, the process of strengthening character education is formed and takes place with the media of early childhood Fairytale Book Collection: Privilege of Animals.

Keywords: fairy tales, character, religious, nationalist, independent, mutual cooperation, and integrity, early childhood.

\section{A. PENDAHULUAN}

Dongeng merupakan cerita yang menyajikan peristiwa imajinatif dan menyenangkan melalui sikap dan perilaku tokoh-tokonya. Tokoh-tokoh dalam dongeng digambarkan seperti halnya manusia yang melakukan berbagai aktivitas yang merepresentasikan kualitas karakter tertentu. Dengan karakter inilah tokoh-tokoh dipahami oleh anak dalam kaitannya dengan proses mengidentifikasi diri anak. Tokoh dengan karakter baik akan mendapatkan simpati dan empati dari anak (Kurniawan, 2015), sedangkan tokoh yang tidak baik, biasanya tidak akan disukai oleh anak-anak. Tidak heran jika anak-anak yang sering membaca dongeng, maka anak akan mengimitasi sikap dan perbuatan tokoh baik, dan menginternalisasikan karakter tokoh tersebut dalam pemahaman dirinya. Melalui pemahaman diri inilah anak-anak kemudian menjadikan karakter tokoh dongeng sebagai ukuran dalam bersikap. Dari sinilah, melalui proses mengidentifikasi diri tokoh dalam dongeng, anak-anak kemudian belajar menginternalisasikan nilai karakter dari dongeng.

Dari penjelasan inilah, sesungguhnya dongeng memiliki hubungan yang erat dengan karakter anak. Melalui tokoh-tokohnya yang menampilkan karakter, dongeng pun merupakan media yang tepat dalam menyampaikan nilai karakter tertentu pada anak. Fitroh dan Sari (2015) mengungkapkan hasil penelitiannya tentang efektifnya dongeng yang digunakan sebagai media dalam menanamkan nilai karakter pada anak usia dini. Hal ini terjadi karena saat mendongeng seseorang bisa memberikan penekanan, penjelasan, nasihat, dan nilai-nilai karakter penting yang akan dijadikan pedoman anak-anak dalam bersikap. Penelitian Juanda (2018) juga mengidentifikasi tentang nilai karakter yang ada dalam dongeng Suri lkun dan Dua Ekor Burung yang menemukan bahwa dalam dongeng tersebut ada nilai kreatif dan kerja keras, penolong, menghargai prestasi, sikap positif, dan nilai kejujuran. Nilai-nilai karakter ini ditemukan secara otonom memalui analisis isi yang otonom. Penelitian Habsari (2017) mengidentifikasi bahwa 


\section{PENGUATAN PENDIDIKAN KARAKTER ANAK USIA DINI PADA BUKU KUMPULAN DONGENG PAUD KEISTIMEWAAN BINATANG}

dongeng merupakan cerita yang mengandung nilai-nilai moral dan sosial (karakter) yang tepat untuk pembentukan karakter anak. Pembentukkan karakter anak yang harus dilakukan di rumah dan sekolah dengan metode membacakan dongeng, pembiasaan mendengarkan dongeng, dan penciptan lingkungan baca yang mendukung.

Ketiga hasil penelitian di atas menemukan bahwa dongeng merupakan sumber nilai dan karakter yang penting bagi anak dan anak usia dini. Dengan temuan ini, ketiga penelitian di atas kemudian mengembangkan cara-cara yang bisa digunakan dalam mentransformasi nilai potensial karakter dalam dongeng ke dalam diri anak-anak. Hasil penelitiannya menemukan cara efektifnya dengan menjadikan dongeng sebagai sumber bacaan untuk anak yang harus dibacakan, dibaca sendiri, dan diceritakan pada anak. Melalui aktivitas inilah nilai karakter dongeng bisa ditransformasikan dan diinternalisasikan pada diri anak. Dalam posisi temuan ini, maka posisi anak usia dini dipersepsi sebagai individu yang menerima begitu saja nilai karakter dalam dongeng. Padahal, anak-anak usia dini adalah individu yang telah memiliki kepekaan terhadap lingkungan sekitar (Montessori, 2015), yang melalui kepekaannya inilah, anak-anak usia dini belajar nilai dan karakter dari sikap dan perbuatan orang-orang dalam keluarganya. Di sinilah, sebelum anak-anak mengenal karter dari dongeng, anak telah terlebih dahulu mengenal karakter dari lingkungnnya.

Dengan kenyataan inilah, maka salah satu peran dongeng tidak serta-merta berkedudukan sebagai pembentuk, tetapi dongeng juga menjadi media pendidikan penguat, yaitu menguatkan atas karakter-karakter yang sudah ada. Dalam posisi ini, dongeng bagi anak-anak usia dini dijadikan sebagai refleksi untuk menguatkan kembali karakter-karakter baik yang dimiliki dan pernah dipraktikannya dalam kehidupan sehari-hari. Hal ini terjadi karena karakter sesungguhnya adalah perangai yang membedakan anak dengan anak lainnya melalui karakter inilah anak-anak bisa menimbang baik dan buruk suatu perbuatan. Dani (2013) menjelaskan bahwa karakter adalah cara berpikir da berperilaku yang menjadi ciri khas individu (anak) dalam kehidupan sehari-hari. Tidak heran jika anak yang berkarakter adalah anak-anak yang bisa membuat suatu sikap dan mempertanggungjawabkan atas sikap dan perbuatannya dengan baik.

Dari pengertian karakter inilah, setiap anak pasti memiliki karakter. Akan tetapi, untuk membentuk kesadaran yang berkarakter, anak-anak harus selalu diberikan pendidikan karakter karena sifat anak usia dini yang mudah terbentuk oleh stimulasi lingkungannya (Montesori, 2015). Salah satunya perlunya pendidikan lingkungan yang distimulasi oleh dongeng sebagai media dan sumber dalam menguatkan karakter anak-anak. Dongeng ini berperan terus dalam 


\section{Kasmiati}

meneguhkan dan membentuk karakter anak yang berkesinambungan sesuai dengan potensi karakter yang dimiliki oleh anak-anak. Di sinilah, penelitian ini akan fokus pada memosisikan buku Kumpulan Dongeng PAUD: Keistimewaan Binatang karya Heru Kurniawan sebagai sumber dan media dalam menguatkan pendidikan karakter anak. Adapun penguatan peendidikan karakter yang diteliti adalah penguatan pendidikan karakter yang sesuai dengan Keputusan Presiden Nomor 87 tahun 2017 tentang penguatan pendidikan karakter yang meliputi karakter integritas, gotong royong, nasionalisme, dan religius. Dengan penguatan pendidikan karakter inilah, maka penelitian ini fokus pada mengkaji nilai reflektif karakter ini dalam dongeng dan peran nilai karakter ini dalam menguatkan karakter anak dalam kehidupan sehari-hari. Dengan dasar inilah, maka penelitian ini bersifat tekstual-reflektif, yaitu mengkaji secara tekstual dan merefleksikannya dalam kehidupan anak-anak usia dini baik secara psikologis maupun sosial.

\section{B. METODE}

Jenis penelitian ini adalah deskriptif-tekstual yang mengeksplorasi dan mengelaborasi penguatan pendidikan karakter dalam teks buku Kumpulan Dongeng PAUD: Keistimewaan Binatang. Model penelitian deskriptif-teks ini memosisikan teks yang dianalisis dan diteliti secara langsung dan objektif mengenai fenomena-fenomena yang terdapat di dalamnya (Ratna, 2014). Dalam hal ini, jenis penelitian deskriptif-tekstual ini dilakukan dengan penelitian analisis isi (content analysis), yaitu teknik penelitian yang bertujuan untuk membuat inferensi-inferensi yang dapat ditiru (replicable) dengan memperhatikan konteksnya. Dalam deskriptif ini, analisis isi ini ditekankan pada pemaknaan isi, membaca simbol-simbol, dan struktur-struktur yang terdapat dalam karya sastra sebagai teks untuk memahami fenomena penguatan pendidikan karakter dalam teks. Proses penelitian selalu melibatkan dua tahap, yaitu teorisasi dan empirisasi (Singarimbun \& Effendi, 2018). Teorisasi merupakan serangkaian penteorian yang dijadikan sebagai landasan untuk menganalisis dan memahami objek (Ratna, 2014). Sedangkan empirisasi berkaitan dengan pengujian teori-teori pada objek dan fenomena yang menjadi fokus penelitian secara empiris (Babbie, 2016) dalam rangka untuk memahami objek dan fenomena tersebut secara ilmiah. Hasilnya adalah pemahaman dan pemaknaan secara komprehensif mengenai penguatan pendidikan karakter anak usia dini dalam dongeng.

Penelitian dokumen (dongeng) data spesifiknya berupa teks atau wacana (Ratna, 2014) yang di dalamnya mengandung penguatan pendidikan karakter. Oleh karena datanya berupa teks atau wacana, maka teknik pengumpulan data dilakukan dengan teknik baca dan catat. Teknik baca adalah suatu proses aktivitas membaca dengan penuh perhatian yang benar-benar 


\section{PENGUATAN PENDIDIKAN KARAKTER ANAK USIA DINI PADA BUKU KUMPULAN DONGENG PAUD KEISTIMEWAAN BINATANG}

terfokus pada objek penelitian (Ratna, 2011: 245). Analisis data dalam penelitian kualitatif berkaitan dengan proses mencari dan menyusun secara sistematis data-data penelitian dengan cara mengorganisasikan data ke dalam kategori, menjabarkan ke dalam unit-unit, melakukan sintesa, menyusun ke dalam pola, dan membuat simpulan sehingga mudah dipahami oleh pembaca (Bogdan \& Biklen, 2016). Analisis datanya fokusnya pada deskripsi, penjernihan, dan penempatan data pada konteksnya yang dideskripsikan dengan kata-kata (Faisal, 2010) dengan tujuan untuk menghasilkan dan mengungkapkan makna-makna dan teori baru (Ratna, 2014).

\section{DESKRIPSI TEKS}

Buku Kumpulan Dongeng PAUD: Mengenal Keistimewaan Binatang sudah cetakan ke-3 sejak Januari 2019 dan diterbitkan oleh Penerbit Bhuana IImu Populer-Gramedia Group. Buku ini adalah buku untuk anak-anak usia dini yang berisi 20 dongeng tentang keistimewaan binatang yang dinarasikan dengan singkat dan padat sehingga dapat dibacakan sekali duduk pada anakanak usia dini. Dalam setiap dongengnya, selain menarasikan dongeng yang singkat (4-6 kalimat dalam setiap halama) dihidupkan dengan ilustrasi gambar-gambar yang menarik, imajinatif, dan kaya warna ini mampu menghidupkan imajinasi anak-anak saat membaca atau dibacakan buku dongeng ini.

Dari sinilah, dapat diidentifikasi kekuatan dan keistimewaan buku ini ditinjau dari: pertama, konsentrasi narasi cerita yang padat dan mudah dipahami oleh anak-anak sehingga saat narasi itu dibaca atau dibacakan, anak-anak akan paham dan suka dengan dongengnya. Kedua, isi dongeng yang manerik dan imajinatif berdasarkan pengalaman anak-anak membuat anak-anak merasa terlibat saat membaca atau dibacakan dongeng-dongeng ini, dan saat senang itulah, dengan nilai dongeng yang kaya dengan karakter baik, maka anak-anak pun akan senang melakukan proses identifikasi dirinya melalui buku dongeng ini. Ketiga, selain narasi dan isi dongeng yang baik, dongeng-dongeng dalam buku ini disajikan dalam ilustrasi yang hidup, imajinatif, dan kaya dengan warna yang memikat sehingga anak-anak pun suka bahkan takjub dan terpukau.

Dengan tiga keistimewaan inilah, maka aspek nilai karakter sebagai materi didukung dan ditunjang dengan baik oleh narasi, isi, dan ilustrasi yang membuat anak-anak usia dini semakin menyukai buku dongeng ini. Rasa suka yang kuat inilah yang kemudian membuat optimalnya kerja pikiran bawah sadar anak-anak (Montessori, 2015) dalam menimati dongeng, memanjakan imajinasi, dan mengembangkan pemahaman nilai karakter sebagai pondasi untuk merefleksikan 


\section{Kasmiati}

dirinya. Dari sinilah, proses penguatan pendidikan karakter terbentuk karena anak-anak usia dini yang menikmati dongeng akan dengan serta merta merefleksikan dirinya. Dari sinilah, narasi, materi, dan ilustrasi yang baik dalam buku dongeng ini mampu menjembatani anak-anak untuk memahami dan merefleksikan diri dalam konteks penguatan pendidikan karakter yang ada dalam buku dongeng ini.

\section{PENGUATAN PENDIDIKAN KARAKTER ANAK USIA DINI}

Proses penguatan pendidikan karakter anak melalui dongeng dimulai dari aktivitas membaca atau dibacakan dongeng-dongeng ini. Saat anak-anak membaca atau dibacakan dongeng, maka anak-anak memahami nilai karakter dari bahasa (lisan atau tulis) yang menyampaikan isi dan nilai serta ilustrasi yang menghidupkan imajinasi, isi, dan nilai. Dari kedua hal inilah, bahasa dan ilustrasi anak-anak menyerap banyak hal yang ada dalam dongeng, termasuk nilai karakter. Adapun nilai karakter penting yang menjadi nilai penguatan dalam dongeng-dongeng buku ini adalah religius, nasionalis, gotong-royong, mandiri, dan integritas. Kalima nilai karakter inilah yang akan dibahas dalam penelitian ini.

\section{Penguatan Pendidikan Karakter Religius}

Religius adalah sikap dan perilaku yang patuh dalam melaksanakan ajaran agama yang dianutnya, toleran terhadap pelaksanaan ibadah lain, dan hidup rukun dengan pemeluk agama lain (Sumar, 2018). Dari sinilah karakter religius berkaitan dengan sifat kepatuhan seseorang pada Tuhan melalui pelaksanaan ibadah dan sikap saling menghormati keberbedaan agama. Karakter religius ini merujuk pada dua sikap penting, yaitu ketaatan pada agama sendiri dan penghormatan yang tinggi pada agama orang lain yang berbeda. Dengan dua sikap religius ini, maka anak-anak akan selalu mematuhi perintah-Nya dan menghormati anak yang berbeda keyakinan atau agamanya.

Dalam buku dongeng yang diteliti, karakter religius terdapat pada dongeng Belut Sembunyi di Lumpur yang menceritakan kenyataan Belut yang berbeda dengan Cacing, yaitu berbeda dalam keyakinan kehidupannya. Namun, dalam keberbedaan ini, Belut dan Cacing memilih untuk hidup rukun dan damai. Sebabnya, keyakinan keduanya bahwa keberbedaan keyakinan itu boleh, tetapi kebersamaan dalam melakukan berbagai kegiatan harus dijaga. Hal ini menyiratkan penguatan pendidikan karakter anak dari aspek pemahaman terhadap keberbedaan keyakinan. Keberbedaan itu harus disadari dan dihormati karena lebih dari sekadar 


\section{PENGUATAN PENDIDIKAN KARAKTER ANAK USIA DINI PADA BUKU KUMPULAN DONGENG PAUD KEISTIMEWAAN BINATANG}

perbedaan, kedua binatang itu lebih memprioritaskan kepentingan hidup bersama yang lebih besar dari sekadar keberbedaan keyakinan.

Untuk itulah, melalui dongeng dalam buku ini, secara langsung, setelah anak membaca atau dibacaakan dongengnya, maka penguatan pendidikan karakter akan terbentuk dalam ruang nilai-nilai religius anak-anak usia dini. Proses penguatan pendidikan karakternya terbentuk dari kesenangan anak-anak usia dini dibacaan dongeng-dongeng dalam buku ini. Kesukaan ini akan membuat anak-anak usia dini mengerti dan paham dengan isi dongeng. Dengan pemahaman isi dongeng tentang karakter religius ini, anak-anak usia dini ini kemudian melakukan refleksi pemahaman karakter religius dengan kehidupannya sendiri berdasarkan pada pengalaman nyata yang dijumpainya. Dari sinilah, anak-anak usia dini mendapatkan penguatan karakter yang terkait dengan sikap religius anak yang berupa penghormatan atas teman-teman yang berbeda keyakinannya.

\section{Penguatan Pendidikan Karakter Nasionalis}

Nasional adalah negara atau tanah air. Nasionalis berarti orang yang mencintai nusa, negara, dan bangsa sendiri yang dibuktikan dengan sikap orang itu dalam memperjuangkan kepentingan bangsanya. Artinya orang itu akan selalu melakukan segala hal demi bangsanya atau untuk kepentingan bangsanya. Dilihat dari serapan kata "nationalism", sering diartikan sebagai paham kebangsaan yang mengandung makna kesadaram dan semangat untuk mencintai bangsa dan negara sendiri (Setiawan, 2016). Dari sinilah sesorang dikatakan nasionalis jika orang itu menunjukkan dua sikap penting, yaitu cinta kepada bangsa, tanah air, dan negara dan rasa cintanya itu diaktualisasikan dalam bentuk perbuatan dan tindakan dalam melakukan segala sesuatu dengan berorientasikan pada kepentingan bangsa dan negara.

Dalam buku yang diteliti hanya ada satu dongeng yang mengaktualisasikan penguatan pendidikan karakter nasionalis, yaitu deongang Kelelawar Keluar Malam Hari. Dongeng ini menceritakan Kelelawar lebih suka keluar malam dibandingkan keluar siang. Namun, walaupun keluar malam hari, Kelelawar sangat menyukai dan mencintai tempat tinggalnya. Jadi, sejauh apapun kelelawar itu pergi jauh, Kelelawar tetap pulang ke rumahnya. Konsep karakter nasionalis dalam dongeng ini berpijak pada pinsip cinta pada tempat tinggal (tanah air) yang kemudian terkespresikan pada sikap perjuangan untuk pulang kembali pada tanah air yang telah menjadi tempat hidup Kelelawar. Kelelawar tidak pernah goyah pada keindahan tempat lain yang selalu 


\section{Kasmiati}

dilihatnya. Bagi Kelelawar tempat terbaik adalah tempat yang telah menjadi tempat kelahiran dan tempat tinggalnya.

Dengan konsep karakter seperti ini, maka saat anak-anak membaca dongeng ini, anakanak akan memahami nilai karakter tentang Kelelawar yang cinta terhadap tempat kelahirannya. Sekalipun tempat kelahiran kelelawar gelap, tetapi kelelawar cinta. Sekalipun tempat lain jauh lebih indah dari tempat tinggal kelelawar, tetapi Kelelawar tetap memilih tempat terbaiknya adalah tempat yang menghidupinya selama ini. Kesadaran ini akan menguatkan keadaan anakanak untuk suka pada rumahnya (Indonesia). Rumah tempat anak-anak dilahirkan dan dibesarkan. Karakter Kelelawar pun menguatkan karakter pada anak tentang sikap cinta rumah atau tanah air. Rasa cinta yang didasarkan pada keinginan untuk selalu pulang ke rumah setiap kali telah melakukan perjalanan jauh dan selalu menerima rumah kita dengan rasa cinta apapun keadaannya. Ini semua terjadi karena di rumah atau tanah air itulah anak-anak dilahirkan dan hidup.

\section{Penguatan Pendidikan Karakter Gotong Royong}

Gotong-royong adalah sikap bekerja bersama-sama antara satu orang dengan orang lain atau sekelompok orang dalam masyarakat dalam menyelesaikan masalah. Misalnya, bergotongroyong dalam mengerjakan atau membuat sesuatu pada kehidupan masyarakat. Menurut Pawane (2016) gotong royong adalah nilai-nilai tradisional dan modal sosial yang mengatur pola dan semangat hidup yang didasarkan pada kepercayaan, keterbukaan, saling peduli, saling menghargai, dan saling menolong. Gotong royong merupakan salah satu bentuk solidaritas dari masyarakat tradisional. Semua masyarakat saling berhubungan dan berkaitan satu sama lain dan bekerja sama untuk mencapai tujuan bersama. Di sinilah, sikap atau karakter yang gotongroyong dibentuk atas kesadaran bekerja sama dengan orang lain dan keinginan bersama untuk menyelesaikan persoalan secara bersama-sama. Dua karakter inilah yang menguatkan seseorang untuk melakukan tindakan gotong royong.

Penguatan karakter gotong-royong dalam buku terdapat pada dongeng Leher Panjang

Jerapah, Kodok Melompat, Tubuh Belang Zebra, Lampu Laron, Lidah Panjang Katak, Sengat Lebah, Sayap Indah Kupu-Kupu, dan Monyet Suka Pisang. Dalam dongeng-dongeng tersebut menyajikan cerita antartokoh dongeng yang sama-sama memiliki kesadaran untuk saling membutuhkan yang membuat tokoh-tokoh saling bekerja sama dalam menyelesaikan masalah. Misalnya dalam dongeng Lampu Laron yang menceritakan Laron yang sedih karena tidak 
memiliki lampu. Laron pun mengiginkan adanya teman yang mau membantunya untuk bekerja sama mencari lampu Laronnya. Salah satu teman yang memiliki kesadaran ingin membantu Laron adalah Kunang-kunang. Dengan dua kesadaran saling membutuhkan dan ingin membantu inilah, maka Laron dan Kunang-kunang kemudian mencari lampu sampai ditemukan. Usaha gotong-royon keduanya dalam menyelesaikan maslaah Laron pun berhasil karena kerja sama dengan Kunang-kunang.

Nilai karakter inilah yang akan menguatkan karakter gotong royong pada anak usia dini. melalui dongeng-dongeng dengan karakter gotong-royong ini, maka anak-anak usia dini yang dibacakan dongeng-deongeng dalam buku ini akan memahami adanya binatang-binatang yang saling bekerja-sama dan bergotong-royong saling membantu dalam menyelesaikan persoalan. Hal inilah yang kemudian akan menguatkan karakter anak usia dini. Anak-anak usia dini secara kesadaran telah mengerti tentang pentingnya membantu dan bekerja sama dalam melakukan gotong-royong. Pemahaman akan hal ini menjadi kuat setelah dibacakan dongeng-dongeng dalam buku ini karena banyak mengandung nilai gotong-royong yang akan menguatkan karakter anak-anak usia dini.

\section{Penguatan Pendidikan Karakter Mandiri}

Mandiri berarti suatu keadaan atas seseorang yang dapat berdiri sendiri dan tidak bergantung pada orang lain. Menurut Sumar (2008) mandiri adalah sikap dan perilaku yang tidak mudah bergantung pada orang lain dalam menyelesaikan tugas-tugas atau kemampuan seseorang untuk mewujudkan keinginan dan kebutuhan hidupnya dengan kekuatan sendiri (Nasution, 2019). Dari sinilah karakter mandiri seseorang terbentuk karena kesadaran bahwa dirinya bisa melalukan sesuatu. Dari kesadaran diri inilah, kemudian diteruskan dalam bentuk sikap kerja keras secara mandiri dalam mewujudkan keinginan atau menyelesaikan persoalan. Mandri ini berarti suatu sikap pendirian dalam bekerja yang didasarkan pada kemampuannya sendiri.

Dongeng-dongeng yang menyampaikan karakter mandiri adalah Burung Bisa Terbang, Ikan Berenang, Suara Meong Kucing, Cahaya Kunang-Kunang, Kokok Ayam Jago, dan Rumah Cecak. Dongeng-dongeng ini menyajikan tokoh-tokoh yang mau bekerja keras secara mandiri dalam menyelesaikan berbagai persoalan yang dihadapinya. Mislanya, dalam dongeng Burung Bisa Terbang yang menyajikan tokoh Burung yang memiliki keinginan kuat untuk bisa terbang. Atas keinginan kuatnya, Burung kemudian belajar terbang secara mandiri tanpa mengenal lelah. 


\section{Kasmiati}

Sehingga, setelah bekerja keras dengan mandiri, Burung kemudian bisa menguasai keterampilan terbang dengan baik.

Nilai karakter mandiri ini akan menguatkan karakter anak yang membaca dongengdongeng dalam buku ini. Proses penguatan karakternya terjadi karena anak-anak akan suka dongeng-dongeng dalam buku sehingga saat dibacakan anak-anak akan antusias dalam mendengarkan dongeng. Melalui kegiatan mendengarkan ini, anak-anak kemudian paham dengan cerita dongeng dan isinya. Saat itulah, anak-anak kemudian akan tertarik dengan tokohtokoh yang menekspresikan sikap-sikap mandri dalam bekerja keras. Dari sinilah, penguatan pendidikan karakter mandiri ini terbentuk melalui kegiatan membacakan dongeng dalam buku ini secara intensif. Penguatan karater mandirinya dimulai dari rasa suka anak terhadap dongeng yang kemudian berkembang menjadi pemahaman atas nilai mandiri yang menginternal menjadi karakter yang menguatkan kepribadian anak-anak.

\section{Penguatan Pendidikan Karakter Integritas}

Pengertian integritas merujuk pada mutu, sifat, atau keadaan yang menunjukkan kesatuan yang utuh sehingga memiliki potensi dan kemampuan yang memancarkan kewibawaan; kejujuran. Basri (2015) mengidentifikasi integritas sebagai suatu sikap yang merujuk pada konsistensi antara tindakan dengan nilai-nilai dan prinsip kebaikan serta ucapan. Dalam etika, integritas diartikan sebagai kejujuran dan kebenaran dari tindakan seseorang. Dari sinilah, integritas terbentuk dalam kesatuan tiga dimensi kehidupan manusia, yaitu pikiran, perkataan, dan tindakan. Tentu saja, orang yang berintegritas adalah orang yang antara pikiran, perkataan, dan tindakan dalam satu visi kebenaran yang dilakukan secara bersamaan dalam satu kebenaran.

Dalam buku ini, ada empat dongeng yang merepresentasikan karakter integritas: Semut Kecil, Belalai Gajah, Susu Sapi, dan Ekor Cecak. Keempat dongeng ini menyajikan cerita tentang sosok atau tokoh binatang yang memiliki prinsip dan keyakinan sama, yaitu suatu sikap berkorban yang terbentuk atas keyakinan, perkataan, dan tindakan yang padu. Misalnya, dalam dongeng Semut Kecil yang menceritakan tokoh Semut yang memiliki keyakinan baik, selalu berkata baik, dan bertindak baik pula. Dengan kenyataan ini, maka Semut pun melakukan tindakan pengorbanan demi menolong atau menyelamatkan temannya, Gajah. Pengorbanan Semut pada Gajah tidak memiliki kepentingan. Semua melakukan tindakan berkorban karena 
PENGUATAN PENDIDIKAN KARAKTER ANAK USIA DINI PADA BUKU KUMPULAN DONGENG PAUD KEISTIMEWAAN BINATANG

berdasarkan pada pendirian dan prinsip hidupnya yang selalu dijunjung tinggi dalam segala perkataan dan perbuatan.

Dengan nilai karakter integritas inilah, saat anak-anak membaca dongeng ini, maka proses penguatan pendidikan karakter terjadi. Anak-anak akan memahami tokoh-tokoh binatang yang baik, yaitu binatang yang memiliki prinsip hidup yang baik, selalu berkata yang baik, dan melakukan perbuatan baik. Adapun bentuk penguatan karakter integritasnya terwujud dalam sikap rela dan mau berkorban untuk binatang lain. Integritas inilah yang akan dipahami oleh anak-anak. Dari pemahaman ini, anak-anak kemudian merefleksikan dirinya untuk melakukan tindakan yang sama seperti yang dilakukan oleh tokoh utama dalam dongeng. Proses refleksi inilah yang menguatkan pendidikan karakter integritas dalam diri anak-anak.

\section{E. KESIMPULAN}

Berdasarkan pada hasil analsis yang telah dilakukan, maka dapat disimpulkan bahwa pertama, buku Kumpulan Dongeng PAUD: Keisitimewaan Binatang menghadrikan lima penguatan pendidikan karakter, yaitu karakter religius, karakter nasionalis, karakter mandiri, karakter gotong-royong, dan karakter integritas. Setiap karakter ini disajikan dalam dongengdongeng yang ada dibuku dengan direpresentasikan oleh tokoh-tokoh binatang yang menjadi tokoh utama penceritaan dalam dongeng. Kelima penguatan pendidikan karekter ini disajikan dalam cerita dongeng-dongeng yang menarik dari aspek narasi, isi-materi, dan ilustrasi yang dampaknya membuat anak-anak suka dengan dongeng-dongeng buku ini. Rasa suka inilah yang membuat proses penguatam pendidikan karakter terjadi.

Kedua, penguatan pendidikan karakternya terbentuk melalui rasa suka anak-anak usia dini dengan dongeng-dongeng dalam buku ini, sehingga anak-anak usia dini antusias saat dibacakan buku dongeng ini. Sikap antusias ini membuat anak-anak usia dini suka dengan cerita dalam dongeng. Rasa suka ini kemudian membuat anak-anak usia dini paham dengan isi dongeng, yang kemudian mengkondisikan anak-anak usia dini untuk melakukan refleksi, yaitu menghubungan isi cerita dan nilai karakter dalam dongeng dengan kehidupan sehari-hari anak. Dari sinilah anak-anak kemudian melakukan penguatan pendidikan karakter religius, nasionalis, mandiri, gotong-royong, dan integritas dalam diri anak-anak. Dari sinilah, proses penguatan pendidikan karakter terbentuk dan terjadi dengan media buku Kumpulan Dongeng PAUD: Keistimewaan Binatang. 


\section{Kasmiati}

\section{DAFTAR PUSTAKA}

Babbie, Earl. 2006. Menerapkan Metode Penelitian Survai untuk Ilmu-ilmu Sosial. Yogyakarta: Citra Pustaka Offset.

Basri, Faisal. 2015. Integritas Bangsaku Dulu, Kini, dan Sekarang. Jakarta: Gramedia,

Bogdan, Robert C. dan Sari Knoop Biklen. 2016. Qualitative Research for Education: an Introduction to Theory and Methods. Boston: Pearson Press.

Dani, Irfan. 2013. Pendidikan Karakter. Bandung: Nuansa.

Faisal, Sanipah. 2010. Format-format Penelitian Sosial. Jakarta: Penerbit Raja Grafindo Persada.

Fitroh, Siti Fajriyana dan Evi Dwi Novita Saru. 2015. "Dongeng sebagai Media Penanaman Karakter pada Anak Usia Dini" dalam Jurnal Pendidikan dan Pengajaran pada Anak Usia Dini, Volume 2 Nomor 2 Tahun 2015, hlm. 95 - 105.

Habsari, Zakia. 2017. "Dongeng sebagai Pembentuk Karakter Anak" dalam Bibliotika: Jurnal Kajian Perpustakaan dan Informasi, Volume 1 Nomor 1 April 2017, hlm. 21-29.

Juanda. 2018. "Revitalisasi Nilai dalam Dongeng sebgai Wahana Pembentuk Karakter Anak Usia Dini" dalam Jurnal Pustaka Budaya, Volume 5 Nomor 2 Juli 2018, hlm. 11-18.

Montessori. 2015. Absort Mind. Yogyakarta: Pustaka Pelajar.

Nasution, Toni. 2019. "Membangun Kemandirian Siswa Melalui Pendidikan Karakter" dalam Jurnal Istimaiyah Vol. 02 No. 01 Januari-Juni 2019.

Pawane, Faisal. S. 2016. "Fungsi Pomabari (Gotong-royong) Petani Kelapa Kopra" dalam Jurnal Holistik, Tahun X No 18/Juli-Desember 2016.

Ratna, Nyoman Kutha. 2004. Teori, Metode, dan Teknik Penelitian Sastra: dari Strukturalisme hingga Poststrukturalisme Perspektif Wacana Naratif. Yogyakarta: Pustaka Pelajar.

Setiawan, Jemmy. 2016. Nasionalisme Retorika Gombal. Jakarta: Gramedia.

Singarimbun, Masri dan Sofian Efendi (Ed). 2018. Metode Penelitian Survai. Jakarta: Pustaka LP3ES.

Sumar, Warni Tune. 2018. Strategi Pemimpin dalam Penguatan Iklim Sekolah Berbasis Budaya Kearifan Lokal (Budaya Huyula). Yogyakarta: Pustaka Pelajar. 